\section{More attention and greater awareness in the scientific study of magic}

\author{
Peter Lamont and John M. Henderson
}

The recent suggestion that we attempt to identify areas of mutual interest to scientists and magicians (Attention and awareness in stage magic: turning tricks into research. Nature Rev. Neurosci. 9, 871-879 (2008)) $)^{1}$ is welcome. After several previous calls for a general psychology of magic or deception, and many preliminary attempts to provide one $^{2-9}$, this more focused approach may have real potential. In order to move forward, however, it is important to be clear on what has been said previously.

For example, we need to be more aware that scientific interest in magic is far from new. After all, the suggestion that an article published in 2005 is "...the first study to have correlated the perception of magic with any physiological measurement" (REF. 1), while perhaps true in the strictest sense, might give the impression that this is a recent area of interest. However, Alfred Binet was studying the perception of magic, and Joseph Jastrow was measuring the physiology of conjurors, back in the 1890s, and psychological interest has continued since ${ }^{2-16}$. Indeed, it is the fact that there has been so little progress despite several attempts to seek some sort of general theory that suggests a more focused approach would be more fruitful.

Similarly, we need to be clear on precisely what is new. For example, the authors provide a comprehensive and systematic list of conjuring effects and their methodological strategies, in which they state that they “...adopt Lamont and Wiseman's classification of conjuring or magic effects into nine categories" (REF. 1). However, it is not merely the list of nine categories but the full systematic breakdown of methodological strategies that was provided in Lamont and Wiseman ${ }^{8}$. If we are clear about what has been said before, we can recognise what progress has been made.

This is at least as important when describing past scientific work.

While the authors rightly see change and inattentional blindness as an area of mutual interest to scientists and magicians, they exaggerate the current state of scientific knowledge. They state that dramatic changes in a visual scene will go unnoticed "...even when people are looking right at the changes", and that, in relation to the wellpublicized study of inattentional blindness by Simons and Chabris ${ }^{17}$, “...observers did not notice the gorilla even when they were looking directly at it." However, there is currently no strong evidence that observers fail to notice either changes or salient objects in the scene while looking directly at the changes or objects themselves. On the contrary, what the current evidence shows is that observers are not attending to what they do not notice, and that when they are looking at a changing object, they notice the change ${ }^{18}$.
The scientific study of magic has the potential to provide genuine insight through the development of specific areas of mutual interest via collaboration with experts in conjuring. With a proper awareness of prior work and present knowledge, we can identify those areas in which new insight can be gained.

Peter Lamont and John M. Henderson are at the University of Edinburgh, Psychology Department, 7 George Square, Edinburgh, EH8 9JZ, Scotland.

Correspondence to P.L. e-mail:plamont@staffmail.ed.ac.uk

1. Macknik, S. et al. Attention and awareness in stage magic: turning tricks into research. Nature Rev. Neurosci. 9, 871-879 (2008)

2. Binet, A. in Annual Report of the Board of Regents of the Smithsonian Institution 555-571 (Washington GPO, 1894).

3. Triplett, N. The psychology of conjuring deceptions. Am. J. Psychol. 11, 439-510 (1900).

4. Randal, J. The Psychology of Deception: Why Magic Works (Top Secret, Venice, California, 1982).

5. Nardi, P. Towards a social psychology of entertainment magic. Symbolic Interaction 7, 25-42 (1984).

6. Hyman, R. The psychology of deception. Annu. Rev. Psychol. 40, 133-154 (1989).

7. Wiseman, R. Towards a psychology of deception. Psychologist 9, 61-64 (1996).

8. Lamont, P. \& Wiseman, R. Magic in Theory: an Introduction to the Theoretical and Psychological Elements of Conjuring (University of Hertfordshire, Hatfield, 1999).

9. Kuhn, G., Amlani, A. \& Rensink, R. Towards a science of magic. Trends Cogn. Sci. 12, 349-354 (2008).

10. Jastrow, J. Psychological notes upon sleight-of-hand experts. Science 3, 685-689 (1896).

11. Ceillier, R. The psychological and technological problems of illusionism. Institut General Psychologique Bulletin 21, 1-42 (1922).

12. Kelley, D. M. Mechanisms of magic and self-deception: the psychological basis of misdirection; an extensional non-Aristotlean method for prevention of selfdeception. In Papers from the 2nd American Congress on General Semantics (ed. Kedig, M.) (Institute of General Semantics, Chicago, 1943).

13. Kelley, H. in Perspectives on Attribution Research and Theory: the Bielefield Symposium (ed. Gorlitz, D.) 19-35 (Ballinger, Cambridge, 1977).

14. Trinkaus, N. Preconditioning an audience for mental magic. Percept. Mot. Skills 51, 262 (1980).

15. Gregory, R. L. Conjuring. Perception 11, 631-633 (1982).

16. Wiseman, R. \& Lamont, P. Unraveling the rope trick Nature 383, 212-213 (1996).

17. Simons, D. J. \& Chabris, C. F. Gorillas in our midst: sustained inattentional blindness for dynamic events. Perception 28, 1059-1074 (1999).

18. Henderson, J. M. in Visual Memory (eds Luck, S. \& Hollingworth, A.) 87-121 (Oxford Univ. Press, 2008). 